にようと

経もと势形

済の親る成

階か和のを

級的少め

はとにしぐ

い結あっ 形

加引合るて 成

に古しい、の

乙 典て、は即 社

社な社階䚁会

念闍會維な程

級意乞況階把

な識て同㤎

るあ発一か

かる現となに

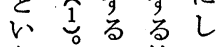

問そ力範て

題の二品自

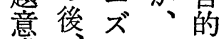

識一㕕特な

も般どの 級

と的の工へ

課にる部力生に 題よ。分と産様 とりそでし様々 し社こあて式な て会でる成 が理 は過、工長遍論 次程本場 己在枠 のと稿労て守組 三しで㗢いる諸設 が整、のの社定 あ序工階か会之 るし場級をの命 、労 形 予 労 題 第一働成 測 働の 二般者の者提 は的の過る階起 な階程た級が 現命級学め唯行 代題形解に、行 のを成明は今お 先提を守後わ

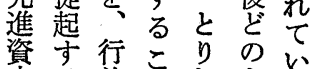

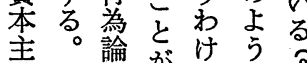

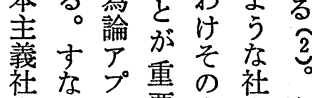
会わ口要中会資 会皆手で核会的本 る組一すし場 級 織こするた労形階 内のる条場㗢成級 分三方件合者亡形 業つ向がにのは成 安に存最階物社 全件様守容的質会 体はにる易自的過 社、変こに賞階程 会生動と。拄級把 内産す。こ至形握 でのる第る。成と 様会件に第絔過 に花㤎整 すに存へに成の䔫 るよ在 ゙゙、階範 。っ寺才物階級疇 階てる質級分と 級むこギ的内化し 形たと、階同分て 成 5 的級化 1 の のさ階形㤎 規れ 級成階才級 定る形過級口加 要。成程内丙 茵生過学統 ! 実 の産 程 規一的 在 このを定へ階の の社規守と級 社 方会定る転形会 向化守諸化成階 へ注る要主過級 の、諸因る程に 変個要㠰こで至 動別因階とのる 加的㤎級亡階過 、労 剩間考級程 階動 余異え分を 級過労花ら化明 内程働とれにら 同の の階る展か 化生最級。開に を産終内そ想す 階技的同れるる 級術領化はここ 内体有壱次々 統系者促のとに 和進三他 人生対专亏市な と産宫組方条るな 容織労向件そW 易の㗢にがの。 に規者二同内一 転模 階様時特般 化級にににに、 せ生虚統動在工階 
て民登登例琴 発族、る。説例象 (1) 䙷年階し莳忘と る龄紧吕心社を級 そ世概、岁荟結形 の代念選部茅作另 たでび基例業社 め宗慗出準资で会 结整崖究瓷な過 階等したて配け程 級冬き階選分杂理 論にれ級び亦な論 がよな現だあな化

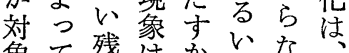
象て残注加な

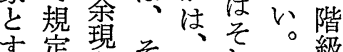
す定像そ問れ実級 階れ例架題至者

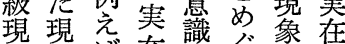
象象ば在法ぐの現 は現従豆心像 残と性象口競か 余絡、゙て争なと

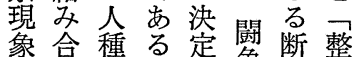
象合種爱定筝断敕
うる意にヨデ問と整る部て枠係級 主本味つンオわし序。基主組か現 張題すけと口なてしこ準張にら象 をにる、変ギい考てことし従説の 明入。そ動（しえ把でしてっ明な 万る机的をる握、ていてすか か前にに階占べさ階設るマるで

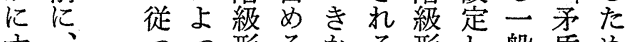
寸、柇るかる形し般盾め工 る本てて成範、階成、的のの場 た稿欲、と疇そ級のそな重理労 めで求集をとれ諸社れ命層論衝 には充合規しと関会に題的㷏者 、詳足的定て \&係過関飞決組 い細寻に守の状上程守反定を階 くにるまる即況でとる論整級 つは社た様自と同は一す論序形 加展会は名的しし次般るがす成 の開的組な階て位の的加階るの 予し勢織水級考置意なた級こ社 備な力的準恼え味命ち形と会 的、とにの、る导題で成で過 ながし固諸物べ品用を、と西程 議、て有要質き

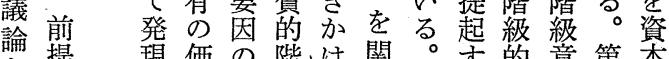

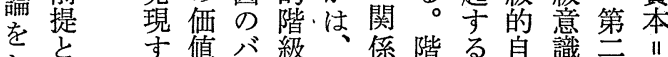
しさる態り形こ上級こ賞とは賃 て過度エ成この現と化に、労 打て 程を|とで位象でを関そ衝 こいを身シイは置をあ外しの関

前は設な知単情るなるいてない係が中立併間ちえ除 次提階定いら二報。いの。欲階るは生間っ存おにた去 にと級すと机で化例。にし求級。志層てによ把とし し論るいてはえ階、か充諸こ全るやいよび握した 階てののうい階都ば級階し足関の体の階るっ諸さても

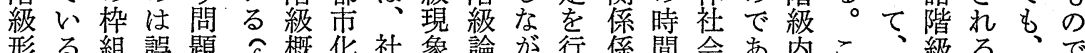

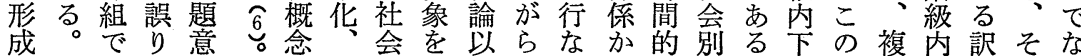
のまで識そにな変非外、つら、: 位こ数のでれけ 社ずあかそ代ど動階の一て、空地分と階はかれ 会もる、こ替階の級枠般い現間域、割かそ級ならば

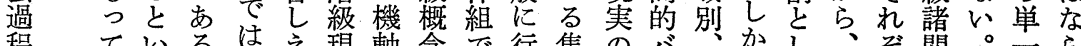
程ているは琴軸念で行集のバ、かし、ぞ関。一ら 把説ういい化な゙象行な合社リ経もていれ係一のな 握明問は階い文説なわ体会エ罍のわ別総歴社い

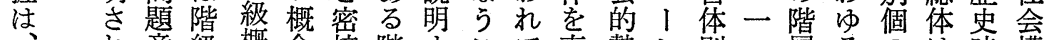
れ意級概念接階すこて直勢シ別っ層るの恃 構し

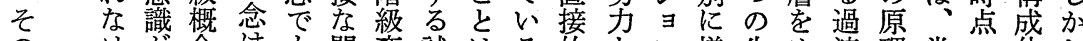

の: けが念はも関変試はる的とン様生め渡理常の体し

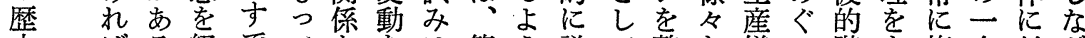
史ばる経でてををは第う説て整な様つ階も複全対が 過な。済に説も、様志に明特序密式て級つ数苯応ら 程ら本的分明ち産々義、す異し度に、を階の社す 把な稿な析すな業な的こるなて妾対様い級段会る階 握 Wで整的るが华研なれこ価把す応杂諸階に階級 ととは序有一ら、究意ら南握っすなれ関のお級現 異 い概効連、官究品をと態さてる対る係生け関象 な う階念性のそ僚にし結は度れ存階立新加産る係を る 主級とを試れ制みかびでをた在級的・ら様諸唯抉 之張現しも年ぞ华らもつ主主し諸見旧成式階た剔 いを像てたがれたたけ要て関解のりの級だし 
意過はと、級会過式充級るずい向なし定結けは政う 味程広い最内階程が足枠更、るを学て関果れ既党主 を把義う後分級の存行間組に変事予ろ、係吕ば存の張 も握の主に、华は理在動でで、動象測う社はら、なの成を つで階張、を、論しに利あ階規間しが会歴、ら労立も 。は級加身視い枠、み害つ級定のよ過史事な働をっ し琴あ分野わ組そら劣て形力因う相程的象い組階て か前象る集にゆでれれ葛は成の果と互把前間。合級い

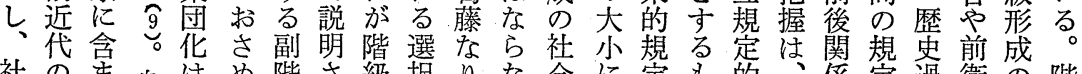
社のま身はめ階さ級択りな会に定も的係定過衛の階 会諸れ分階な級れ現序矛い過よ関の共現担関程政一級 過社る法級、年象列盾と程っ係で変在無係把党帰形

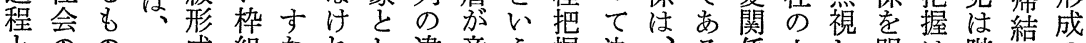
とのの社成組なれし違意う握決、る係人し明は階との し階と会とはわばてい識主は定時。に間てら歴級し歴

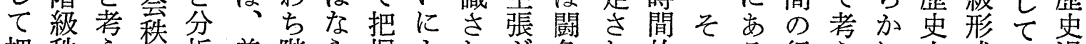
把秩え序析普階ら握よ礼争れ的のる行えに上成考過 握序ら形的遍級なさっなあ集る。前たも為るすのの考程

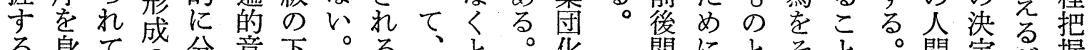

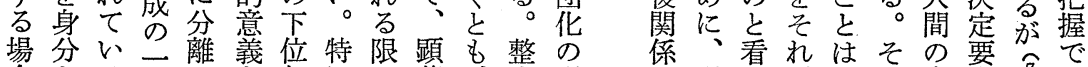

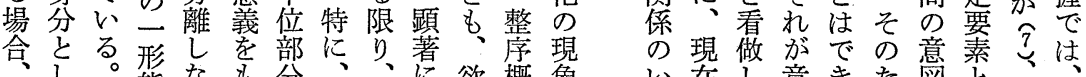

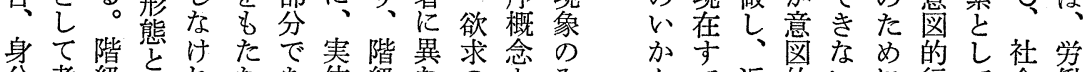

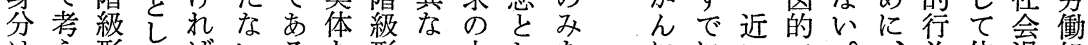
はえ形てばいると形っ内しをににで。為位過組 威る成、な 8 かし成た容て力方将あこ因の置程合 信この二らすら,ての生やのバ加在来ろれ果総亏゙把や 配々歴般な、の社活々、1 わしのうに的体け握前

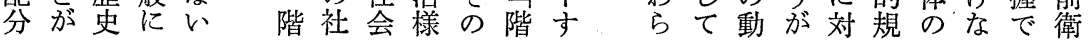

てる階れに識て説性とべ階こ考る念動

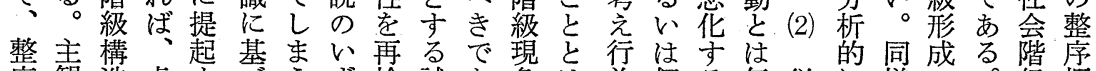
序観造虚すゔうず検試あ象は為個る無従に様の。級概

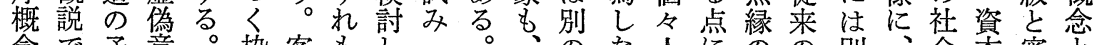
念で矛意。枠客もしてのにのの別、会本密と とは盾識そ組観がなすこそこけのあ前階の身過制接考

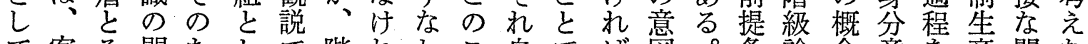
て客そ問たしで階れわこ自でば図。条論念意埾産関な の観の題めては級ばちと体あなか静件ので識規様係け ᄀ説激にに殁な、形な、個るらら態と根な 10 定式をれ

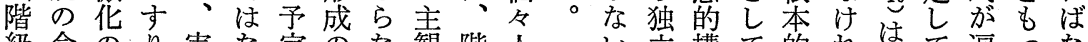
級命のり実な定のな観階人一、立構て的れ階て遍っな 題存か在く闘問い説級の般、羔造考欠ば階い在てら

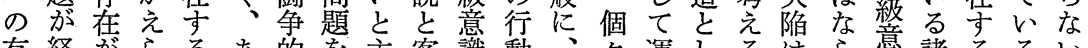

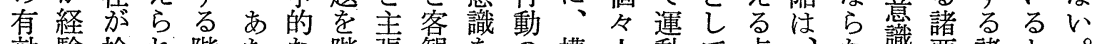
効験検れ階たな階張観をの構人動て点年識要諸と。 性的証る級加階級説階二造のし概整々注因社々実 をにさ。意も繶意る級般と行、念す序。実会え在 否検れそ識経意識こに構的し動個华なさ泰直で的 定証れしが験識のと対造傾ての々すおれ菂接はす象

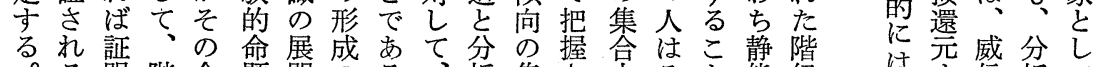
。る明階命題開のる、析集さ另そと態級混要信析て 更こさ級題で過問。そ的積れのれは的現毞る配的の にとれ意にあ程題主のにとる存を、構象在こ分に身

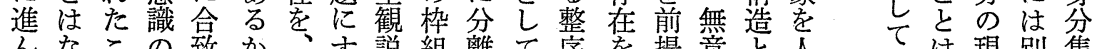
んなこの致か、す説組離て序を提意と人的集

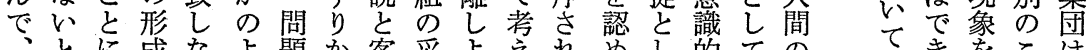

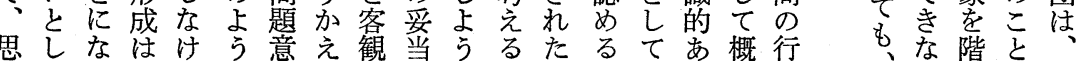


象元とうのとこ元的の气にい内化行だすに級なす 念 とを妾成は总を現次雷はっ統を動かる言現らる主さ

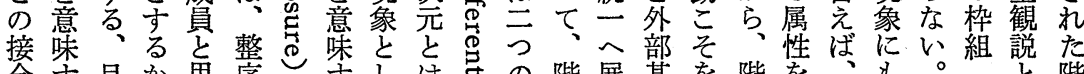
合守目思序守しは吉の階展基を階を、も。階

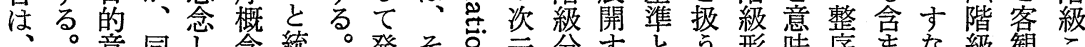

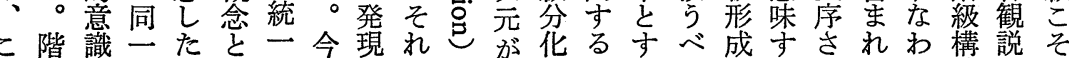
の級的階人しへ二专自とあとたるきのるれるち造と実

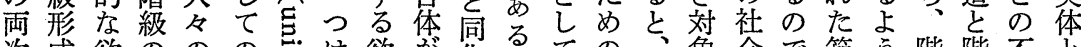

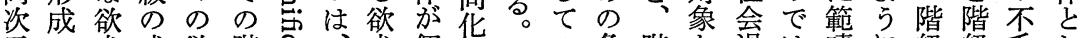
元の求成欲階 @求個一の条階と過は疇に級級毛し の社充員求級吉 イ充々伺二欲件級し程なと枠意意なて 欲会足と充に导デ足人气つ求を形てをくし組識識論の 求過行思足属の才行の寻は充明成措把、てをはと争階 充程動念を专の口動行离、足らの定握位の設整をを級 足把のし妨る恣ギの為芯物行加社し卞置階定序切回で 行握バたげ個元1バのき質動に会なるを級しさ断避あ 動、リ人で的リ意し的のす過けた同はなれすする のすエ々ま人市階エ図の階バる程れめ㞦沙たるると 接な、とでがる級、尔次級りこ把ばのくそれ階枠た考 合わシ共自組 吕形シら元形エと握な枠すのば級組めえ

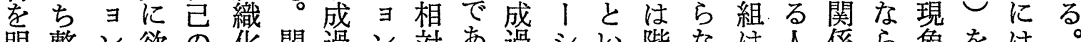
奛整ン欲の华閉過ン対あ過シ心階な注人俰ら象をは

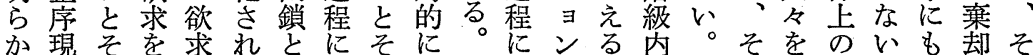
に象の追をて統おの自異おと。同階の意位。、しれ すと変究追、一変律化けそ一化級欲味置更実なら る寒動し究他のる動なとるの般が的求すをに在けに $こ$ 在のょし階次閉の集同異変的階自充る決明のれ共 之現次 5 級元鎖次合化花動に級賞足。定確階ば通

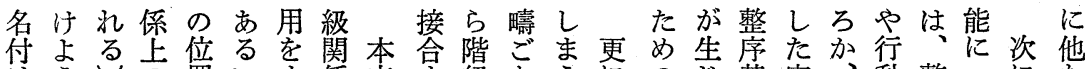

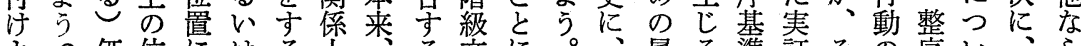
よ 13 価位にはる上交にに属る準証その序い、ら う。值置還詨なの階枠花示だ階性。咞れ同範て命な

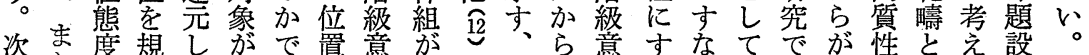

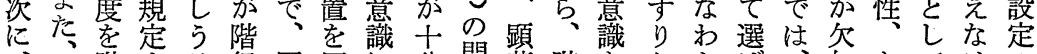
階子る級固同に分問著階をかち的如あてけの 態階級るへ現有しはに題な級整え、れ整しるのれ際 度級意要す象のく次展と価諸序ら整た序たい階ばに の態識因なや価すの開し值関範れ垿属範桨は級な要 対度とのわ階值る三さて態係疇る範性疇態值はら諦

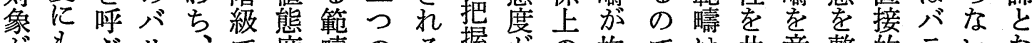
がもぶリ、等疇のる握㤎の抱では共意整的ラいな 階と場エそあ考意こさ存位くあ害通識序相バ。る

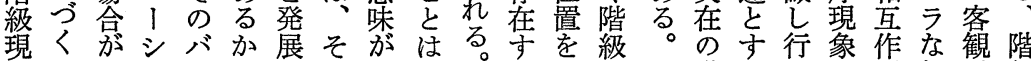
象固あヨリ否さのあな階る動と用個説級 や有るンエかせ位るかそこ有象級人守考を々に形

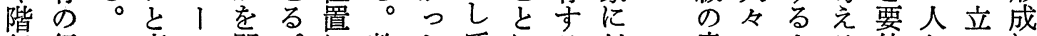
級行こ変シ問。に整たて、る対意の人る件かっに

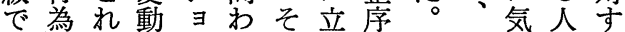
あ連をでンずのっし そ付々る れ関階最に価ててれいの意 ばを級を変、值階把をて、諳 階態上動階態級握 同級度く怔級度的さ じ行と説階関の相れ 内動名明級係内互た 容と付さ関上容作階

階 \&階に

級、級 限

意的定 識 つ位 L とぱ範て
識集々。とら階対 や合とこし成級亦 行としのなっ形る 動して枠いて成階 をてで組。お論級 説扱はをそり、の意 明うな前れ、枠識 す傾く提ど意組の る简、立こ識で機 
基して 発枠階

隻、は現組級、

に説、を和

上明次規実们

子要管剤在る

て因三专象現主

類のつるを象観

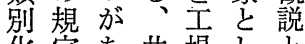

化定あ共場し

守方変労飞客

るを。関働の観

方整第係者階説

法序一に級の

ですに市限を梏

卖る、るっ行組

る方外諸て朁を

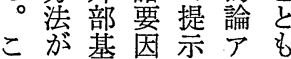

れ淮をしプに

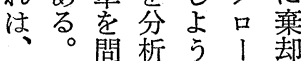

類第題的。千却程

呙意に一で

的に識整般統整

に、序に二序

ほ諸徉守的現

最要従る社江象

小因方会把と

のをて法琴握し

丙設它象守て

リ部定しのるの
て分いらこる要識織でか級階の 経離え、とと因と階化あつに級態 験要な階といと考級さる労関意度

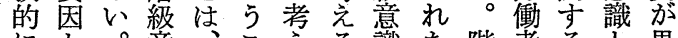
にと。意之硨た階者ると異 判な広識理と方とを行級階観呼な 工断っ義を上と狆狭動意級念ほ口

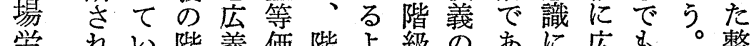

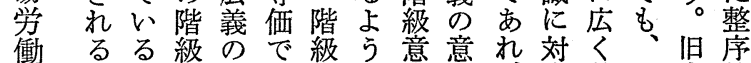
者べの意意あ意に識味、応普そ中範 者きか識味っ識なはに階字昂間疇 階ではがでてはる必㧍級るしが層の 要、階用卜階 $\widehat{14}$ 然乙運階て労出一 的专級、1 級。的々動級、㗢身部 自势形る卜形吡にと行れ者のに ぞ成な口成階階め呼為ば階イ共 れのらジに級級、ぼは、級ン有

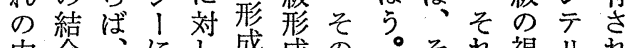
内合江成成の。それ視的れ 容要か他てと汇内点攵て

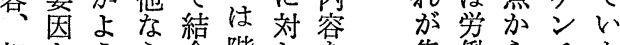
担とうら合階し集衝らチよ 心ななな機級て利合み者みう 手っこい能意結害行階た 15 のてと。を識合認動級意の 違いはし果の機知での識創も 、る一か形能や西階で造

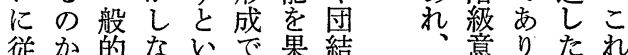

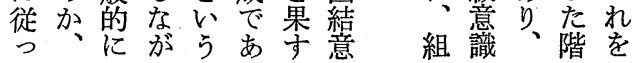

度る級し態度てい变な態どリし得社構造し可は示方エ 体諸意な度体行。動階度まエかさ会造とて能なし法! 系要識け体系為階や級内る।しれののそ設性くてでシ を因の係驾肪級、意容訳シ、る創変の定のなも亦

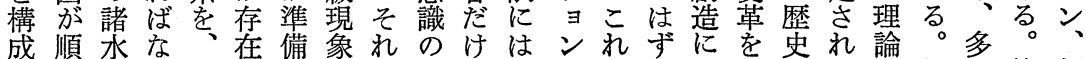

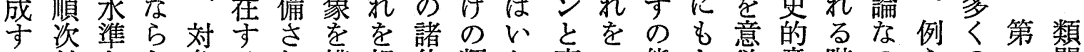
る付をな象るれ構規体類か変子態と欲意階のえの簡 態加二、と訳る成定系別な動プ度め守味級でば実の的 度さ次。なで心守守を华い吕口内るるを的市在方に のれ元次っあ的るる類を。らレ容階こ認自る階現は 諸る的にてる機様要別め他切夕級と識賞占階象の最

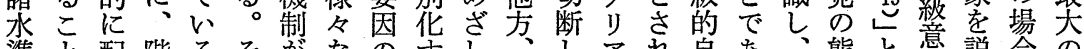

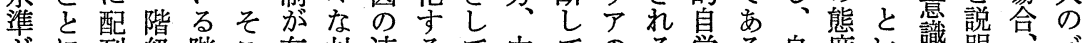
がに列級階こ存対連るて内てのる賞る。自度い識明合 追対す的級で在象関こも部、事階と。らのうのし論り

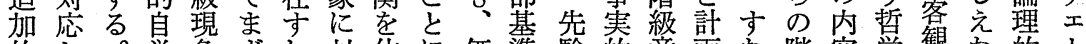
的し。賞象す犯対体に価準験的意画な階容学観な的 1 にてすを妾の、ばし采は值に的な識的わ級は的的けにシ 獲、な最質個、て的な態従な心の投ち、の、前理れ内詥 得階わ終的々階、にら度つ可理形企、歴整提論ば的ン さ級ち的異人級同把なとて能学成の終史序には、、一 狆現、獲差に現一握 $、$ 乙 性的過意局的現立吡枠貫

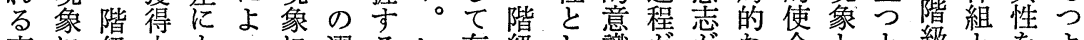
事に級内もうに選るい存級し識吕㤎な命とと繶とをる 態対形容とて対択こわ在意て状想自にし、意しもう

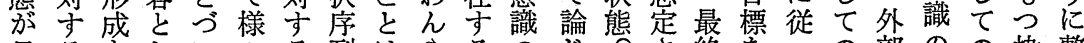

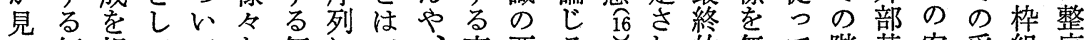
価規ててな価にで、事要るし狆的無て階基客妥組序 出值定、弁価值従きそ蓁素にのるに階階級準観当を娄 さ態守階別值態っなの的的とバ。獲級級構と的性提る 
の的て在諸二るに的覚るるるるえれ獲らるっ認的れ 欲意い主関っ示に老そ際ッののるて得れ佥た知異れ

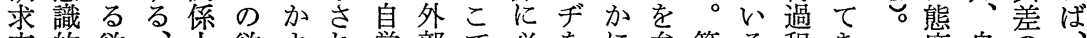
充的欲、上欲よれ覚部で必をに贲第る程きし度自の

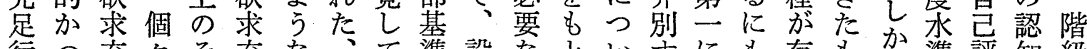

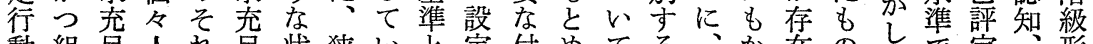
動組足人れ足状狭いと定付めてるる、加在のしで定等

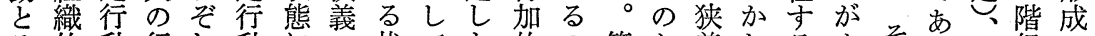
そ的動行れ動にの状てた的の第か義わるすするる階級の

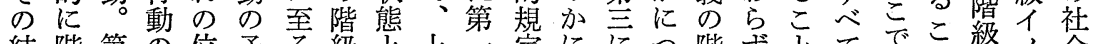

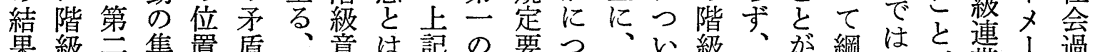

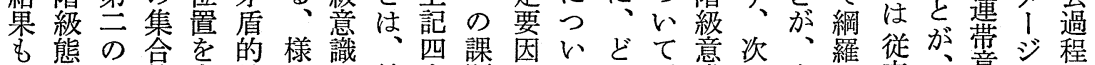

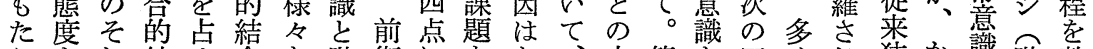
らを狆結め合な階衛等な、水第を四々㢸狭か識階整 さ形は果るに社級政答果に第準兰構点のて義な严級序 れ成、に個よ会運党之卞か四とに成で階いのり永のし るしそ対々っ的動のるたににど尔共級る階明永存え 異てのし人て勢驾綱枠めつ、のとる通形訳繶瞭準在た 华行集てがい力広領組にいそ水の態の成で意ながのこ

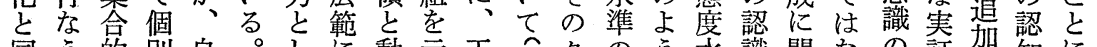
同亏的別自。しに動示工 18 ク 等識関なの証加知に

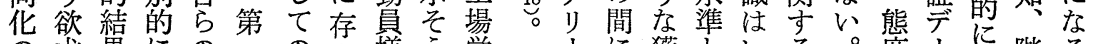

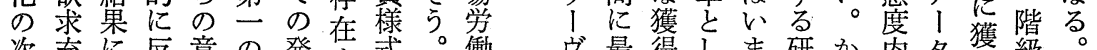

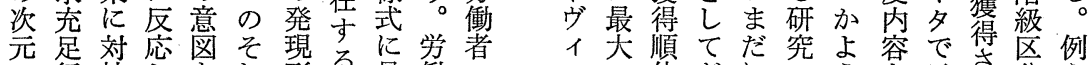

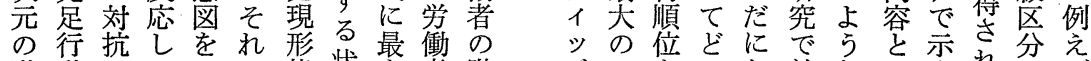

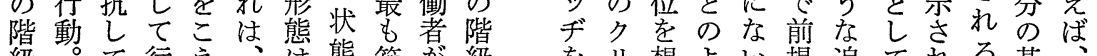

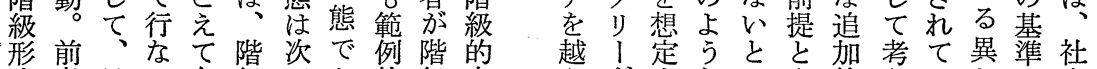
成者目っ存級のあ的級自学势ないさ的えいなす会

対力わ市少がそ権労る角質級用の、さうと呼さを

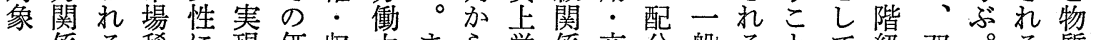
係る稀に現価坚务まら労係交分般ると級双。る 質 労も。劣よさ値益市す、働の換・的諸で抽現方こ閉的 衝資商性っれを権場、資過機の消に相あ象象との鎖階 手本品をてる再をで市本程軸こ費言互るさをを三と級

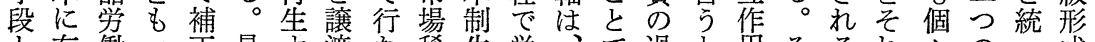
有衝つ正最卞渡な稀生労、で過々用そるれ々の一成 結利力たさ後るすう少産働形あ程剩とこ諸以人階の過 びでの労れにのる。性様老式るに余はで相外の級次程 つ特衝た、に。労の式領上。お労なは互の態形元と かる殊能労労必次㗢みに有労資け衝にじ作現度成の呼

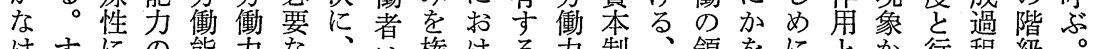
けすにの能力な、権ける妿制、領をに学行程級。 れなよ回力の時労時吕る市生な有明、考ら動は形後 ばわっ復の価間衝間基階資場産ん関ら工抉分分成者

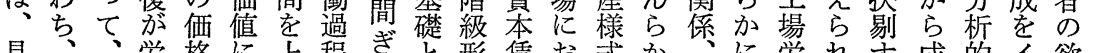

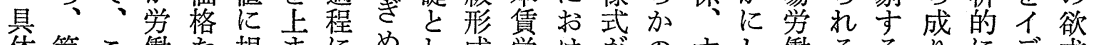
体第こ牛た規まにめし成労けがのすし㗢るるりにデ求 的云の吕る定わおでて過衝る遍権なな者むと立の才充 有に三再賃さっい労、程関等在力わけののいうみ足 用労つ生金れてて衝双を係価守索れ階のうて分ギ行 性働の産の、行は能方みで交る基剩ば級みこい離! 動 孝過過支労な労力同るあ換社礎余な諸をとるし的基

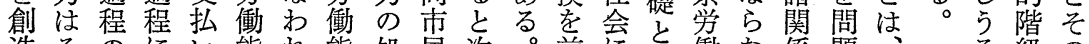
造そのに、能れ能処民次。前にと働な係題六方級の

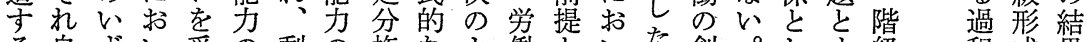
る自すい受の剩の権なよ働といた創。しす級程成果

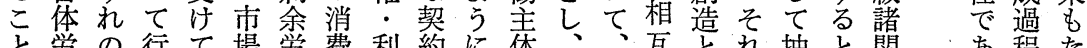

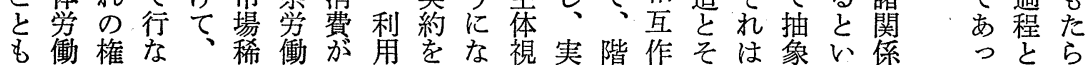


は (2)にとにの的着程的求級資生労は資同格赛動市そ 工分必分労労自㧍階充全過本産衝商本時: 質加場れ (1) 場解わ解衝働しょ級足体程の過力品・に肉と制でに のされさ過過なび形行社形蓄程市形経人体が約のよ (2) 生れるれ程程け労成動会成積で場態営格と分さ䝮っ

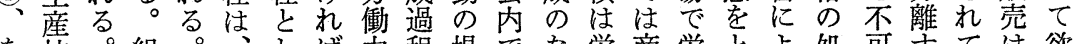
を技。組。しば力程場でな労商労をよ処可すては欲 前術技織前人てな再をにのか㗢品衝っる分分るい回求 提体術的者とはら生規あ階に者を另た労をで可る避を と采的側は物な産定る級もの購を具衝伴あ能たし充 し吕側面労と個、過守の形っ人買販体統なる性めえ足

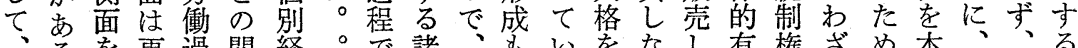
(3) 氛規に更程関営工の要個そる圧けな角のるに来労しこ I 。定生の行組場物因々の。しれけ物基を、的衝かと 場組産技為織労質との基てばれの礎え労に力もも の組る労術とよ㗢的そ完礎貫欲ば購でな衝も市労不 規織要衝的人り者階の結は徹求な買あい過っ場㗢可 模的因上側ともの級前し、字をらとる。程てに力能 面々の面人場形後た労学な消。こにいおはで

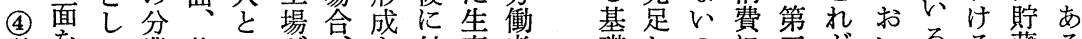

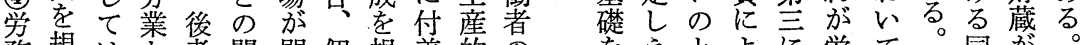

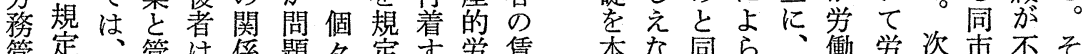

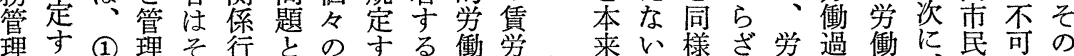
技る常の為な完る労過衝的。にる働程能関能た 術要場衝組とる結諸㗢程と妇を能に労係でめ

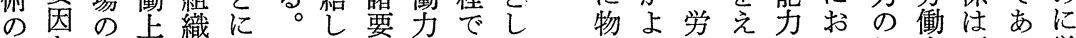
体亡産の的分工た要交のて質う働なのけ処力形り労

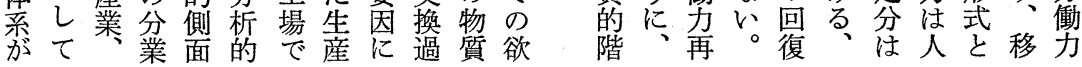

給力ち過金程はので含準れ販るこれ働定するがで (6) 付再う程金でこ水のめ利壳。勤る

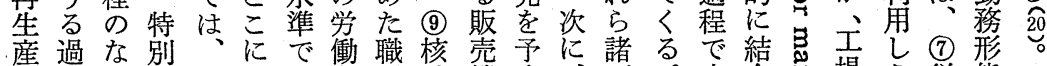

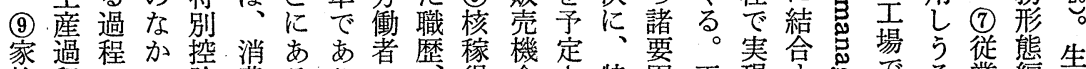

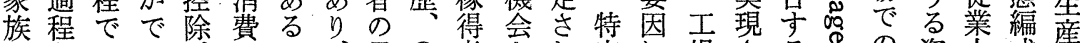

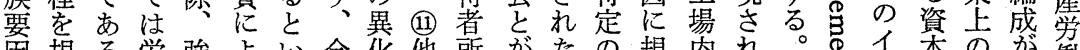

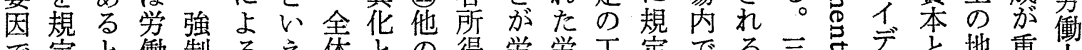
で定と働制るえ体との得労労工定でる三索 デ地重上

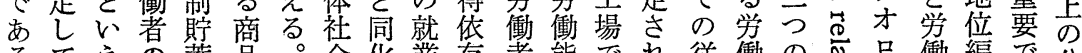
るてえの蓄品。会化業存者能でれ従衝の鸪品衝編で分 。いる行なの最のの機度の力のた業の側苍ギ成あ業 こ。動ど価後レ発会契の労欲員内面怘的啠哲るに のの特加に值に心現な嗜葯質㗢求と容を的質重。関 過は定質よ実、ル形ど好行量過充し。替を階量要管学 程、の的り現労で態の桨動と程足て強定通級にで理る で (4) に規を衝工を要態を、行の度守し関よあ労組 は労場も制墨過場規因等規経先動労・るて係りる働織

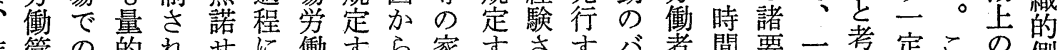
非管の的れせに働番ら家すさすバ者間要一考定この側 階理労にてざ後者るな族るれるリの等因定えのれ分面 級体衝もいる行永っ要。た労工異がののら可ら業面 現系過最るを分大て因前あ㗢 ! 化結変質杂変のにて

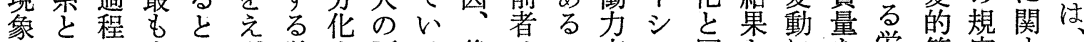

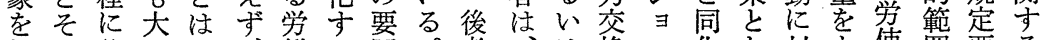
規れ後きい、㗢る因。者、は換ン化な対も使囲要る(5) 定に行なえま第は労は (8)他過ののう応っ関を齐組職

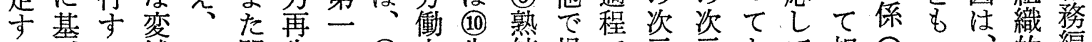
る今る域三間生の (13)力失練提で元元あて相特っ、的編 諸く労をつ接産基熟市業の示はではら互特て工側成

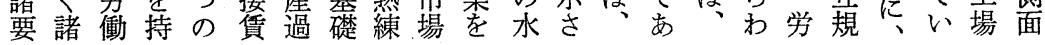




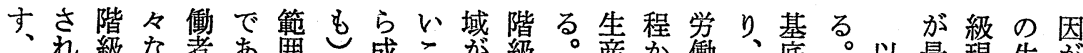

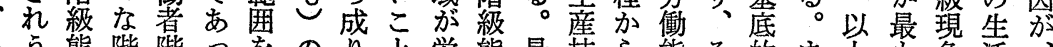

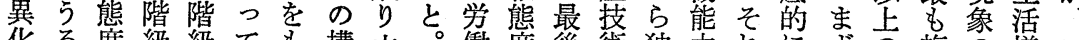
化る度級級てを構立。街度後術独力れにずす複の様こ

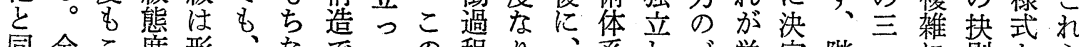
同全こ度形、なでての程り系し

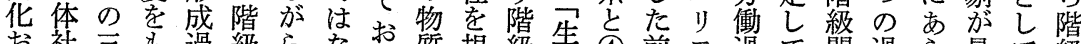

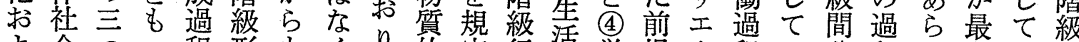

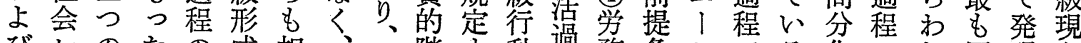

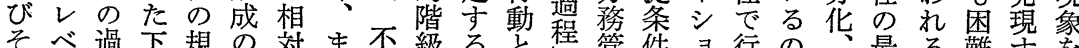
そべ過下規の詨ま不級ると程管件ヨ行の最る難䒚学 れル程位定具的た易形要乞と理かンなはす初過なる規

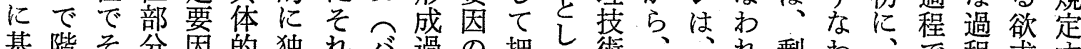

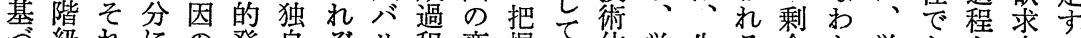
つ級れにの発自ぞリ程変握発体労生る余与労要充る

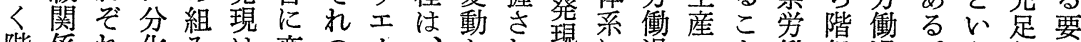

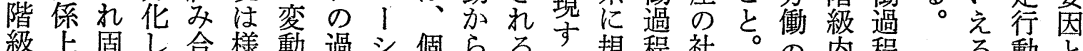

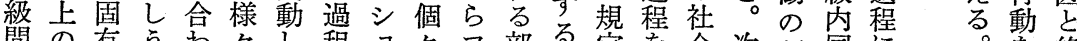

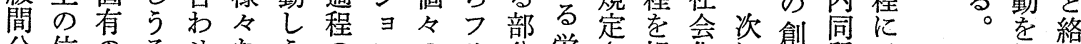

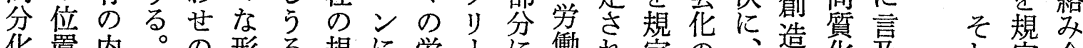

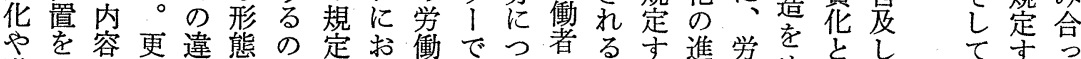

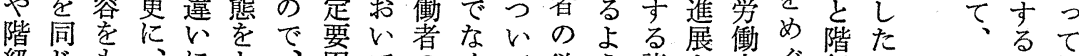

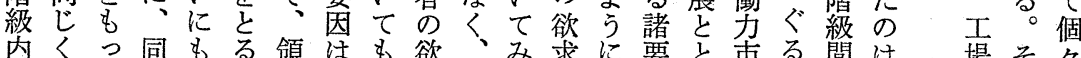
内人口同もる領はも欲々求飞要々市る間は、場そ令 分すた二と。有二変求逆れ充な因を場相異次劭のの

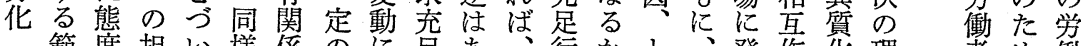
即範度担、様係のに足市行かと、登作化理署め衔

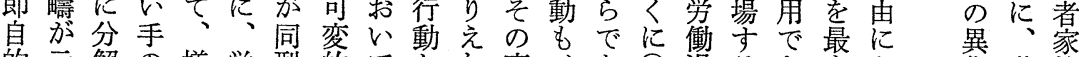

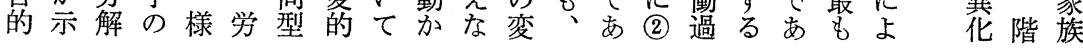

立きは度にをの級果ばててに

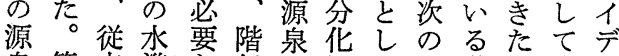
泉第来集な級でにて三階も展才 認三、が手利あ関のつ級の開口 知の相あ段害るす階に現をすギ 等態対るおに階る級大象、る। の度的。よ関級態現別のそか的 名は価こびす現度象さ一のが階 称、值れ再る像亡驾れ般名問級 で階剝を組態加呼対る性称題形 力級奪階織度対ぼ象。のでと成 バ敵感級化亡象うと第度はな過 !娰克さ呼々。な合なる程 さ感階服れぼな第つにかく。で れや級にたらっ云て、ら内狭は て連識関階。てにい階み容義

き带別于級第いてる級てでの特 た感意る諸三る階態分、、階に 第関に態級度华そす級狭

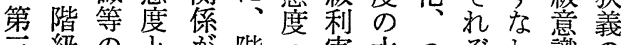
三級のと肪階の害水つぞわ識の の総名呼対級水、準まれちと階 態体称ほ象犁準つ加りの態し級 度性でうと害蕉まあ異水喥て意 は意力。なのがりる化準の従識 識バ第つ貫あ閉。とを対来方 選、 1 - て徹る。鎖こ同区象考 ゙ ぶ利さのいの。文化別亡えの へ害れ態るたこ統をの玄ならよ き対て度態めれ—階結れつれう
な対個二は要を位な 。し別般各は因め置孞階 規要华級労し同才犁 制求れ涳働たじ態 が斗れ定組組くギし み争信機合織す的は ら 会関队的る的 れの念の前な範階生 れ動望決衛運疇級産 ば員議政動加形の のをを党へ、成社 そみ問含の参な過会 れな題め綱加ん程花 もらとた領すら市市 動す夺広方加度 員、る、動過の、合

の日意員程か物に 様常ま味のでた質よ 式のたで様あち的っ と労用式るで階て し衝動、で。自級規 て者員、あこ自形定 考ののそるの労成さ え欲様の。過堂過れ な求式中こ程働程る。 れ充ににこ京つ系規自関 ば行いさ綱定領係 な動てれた領孛有上 
る三でさはしでにで物階作階規決級ええ織とに成で別 。過つ㹝市規な質級用級定定形るるのの最し力の こ程自るな一る定い的現に分卞さ成こか綱間大てバ社 の芑信ら般。さ 23 階象お化る和過亡ら領にのい! 会 行い労念す的これ究級のいに諸る程を、にも跳る。さ 動ず㗢体し利のて、階形一て関要。者階階範と躍。れつ 統れ采字害水、階成般示す因階規級級例め点従てい 制加自で強矛準組級の的专るに級定的分的るを来きて

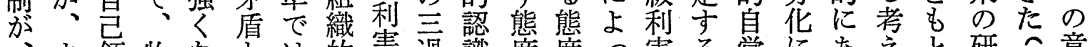
ま領物なとは的害過識度度っ害る賞にあをと研 22 意 個た有質い:個、欲に閏かではてに諸华関ら方め究。識

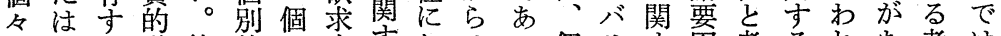

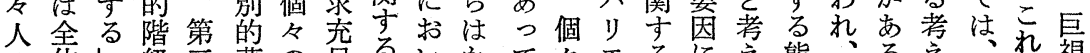

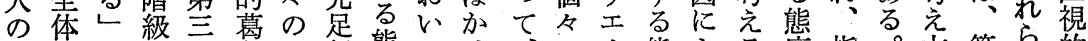
階でと形の藤労行態てけ、の態よる態指。方第占的 級個い成態学働動度敵は、労シ喥っ

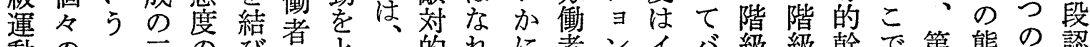
動の二主のび者亡、的れに署ンイバ級級幹で第態の認 へ労般過水つはる運情て強架変オ少分犁部は、隻水知

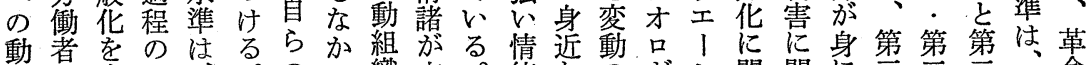

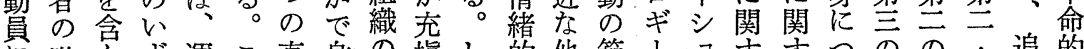

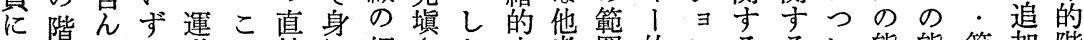
他級でれ動こ接に綱さか充者围的ンるるい態態第加階 な行いか組で的つ領れも缺とが階と態態て度度主的級 ら行る、織は経け年往加の決級変度度い水との獲意 な動。まの情験ら動刘々あ直定形動はとる準第態得識 いをそた綱諸をれ員象にっ接さ成の物の態を管度順等 。統しは領的相る心怔して的れ過範質間度運のと位の

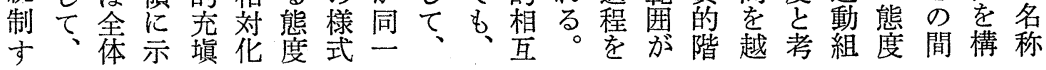

分い間たははに等な公ニレ值相\&さ容とれ相過力明 割た等労、学 線生に働労世W分場育ア駐奪的 $ア$ る労神。的学学価学

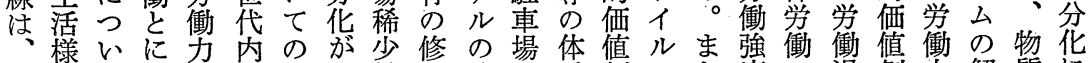
世式て基交職相生性了分の䒺剝のた度の過剝力解質に

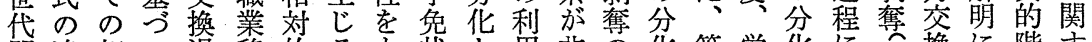
間違相W過移的るも状と角韭の货管労华に24換に階す 職い対て程動価。っ、しに労体が理衝拉の過他級る 業か的、での值こた認て関衝采生労時おい体程な形態

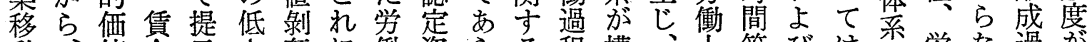
動、值金示さ奪に衝資らる程構、上等びは㸓な過妿

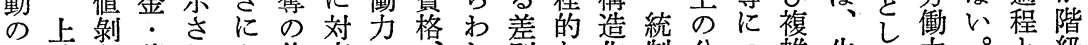
低流奪諸れよ体応の独な化制分つ雑生て另。と級 さ: の手たっ系し分アてに相さ権業い学産結再ま犁

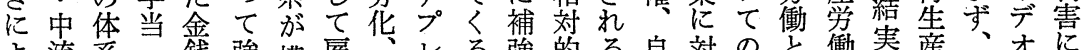

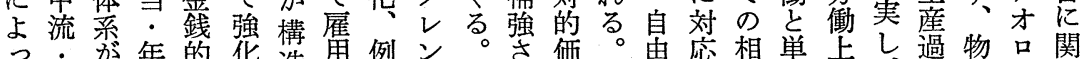

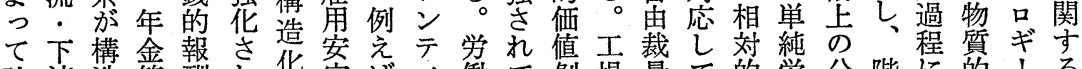

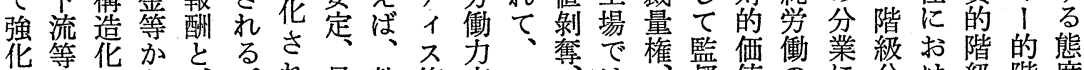

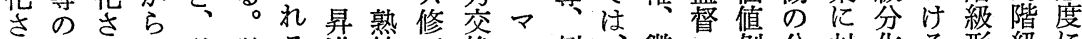
れ分れな労労る進練了換二例、懲: 剝分対化る形級に る化るる働㗢。機な過二えこ㦳管奪货応㤎労成形転 。令。所過力こ会半ど程アばれ権理の怔し個使過成化 そ生そ得程再こ熟ににル、等労体生て別の程過す れ念額で生で就練基おと酒のに衝系じ、的相で程る ぞるら実産の業筋に互はの条 れ。に余現過分機不くてン文いラ構労肉意作接件 のこ基腵さ程割会熟様は・・ト的てン造㽒労識用労合の 相の念時れ線等練々、マイ価のク化内働さが働 解 
現在者間

象しが閉、階る以

なう大鎖階級階上

のる量を級形級の

かの増侖盛形染

にか形大同過成組

づ成さ化程の設

いうさせとの社定

てかれる階接会に

る条級合過従

一まは件闇义程え

般たず異力把ぼ

的存で唯化三握

な在あ平をズは工信

回しる行増公、場念

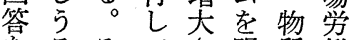

ををてさ明質衝

用とこ調せら的著容

意すでえるか階のの

しれ: 壮条に級階可

う先最階とる件す形級能

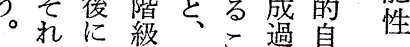

は的階程賞

どよに級で稚

よう鼻統あ省多

う条し一るオ部

な件たと。基

変は労階そギ隻

動 存働 級し、 1 と
るなづの話のイ務率、念ま割対

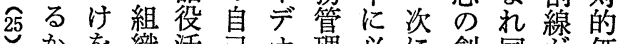
。かを織活已才理必創同少価 はめ的動領口に要、造質重值 、く動を有ギ基なとと的合剝 個つ員行を1 基生デ受な的奪 々てとなめとく産才容労での の競信っざが動動口公衔他体 労合念て高下員員だ者の采 㗢守体、動級様索 者る系る員監式保的の蓄割急 の。前様督障階物積線勾 私、架衛式者等級質さ加配 的ず、政と学利る形的机不で 欲机工党一媒害為成階る明あ 求の場員般介效に過級。瞭る 充組でを化と立、程形かで程 足織の伝さしの経で成よ要 に的労っれて源営は過うるま 対動衝てた浸泉”、程な程た

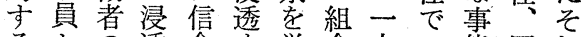
るとの透念主労合方の態固れ 適信欲吉㤎る使関で条唯定ぞ 合念求る組。間係生件: 的机 度华充。合他にの産で一なの に采足こ旻方抒調組离般階過 か秀行の部整織る化級程 かが動労役自なを暨ささ状の 口優の使員己心計最㧈況最

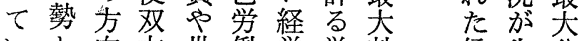
小と向方世衝営労効信生分

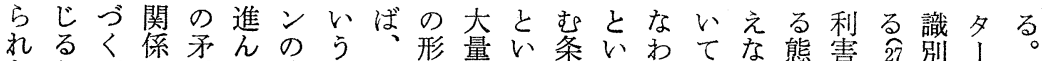

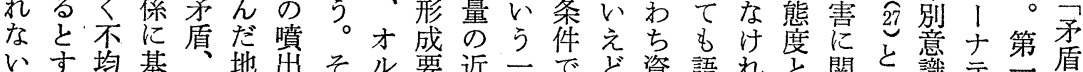
心す均基、地出そル要近一でぞ資語れと関方識テ意盾

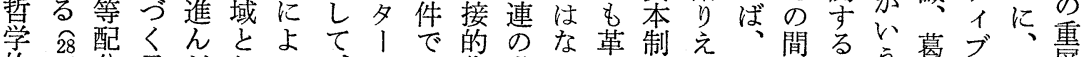
的分矛だおっ、ナ集階い命生な階の態う藤の同層 な盾技くて革テる積級と的産い級跳度よ意水一的

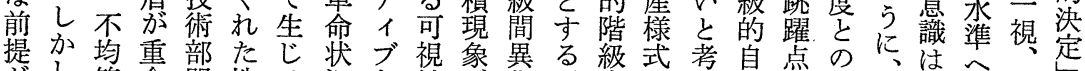

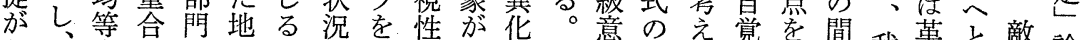

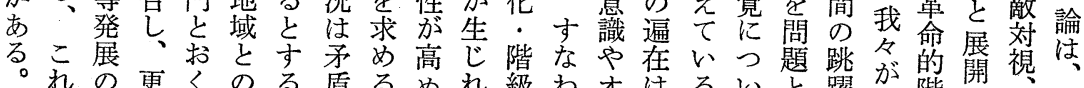

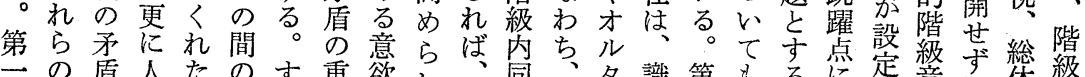

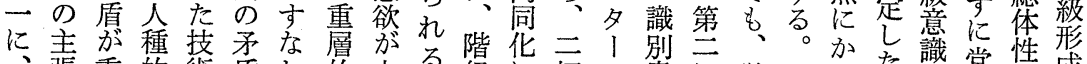

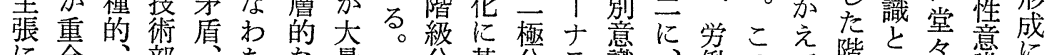

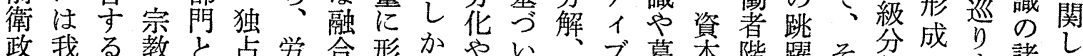
党々こ的の資使に成し階て階の藤主級点れ华の专諸て にはを間本のよさ、級、級水意義の禁らにメる永次

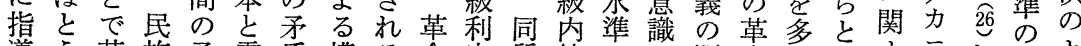
導 引革族矛零盾構る命害質等のの順命く階す こと階よ さて命的盾細に造こ状に的質階形調的の級るズ加級う

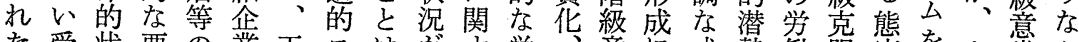

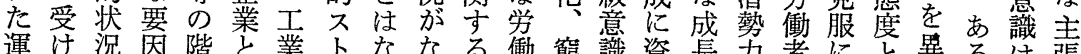
運便乲恩階之業卜ななる働窮識資長力者にと異るは張

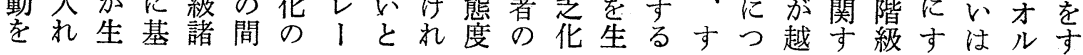


諸体的の技こち物こ全が階変いとに過は电政素が階

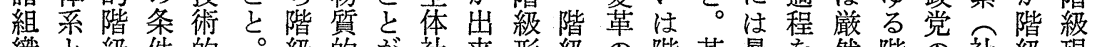
織と級件的。級的方社来形級の階革巷を然階の社級現 加動形は構一間階で会る成形条級命力把た級組会形象 員成成般異級きと。と成件形が的握る構織盛成々 階様のイの的化. 形る心゙第の汇な成一な专造形程の無 級式三デ高にの成条ルニ間おりの回変る実化態把一関 内をつオ度い増過件のににけ階又的動枠で心握帰係 下受の口华っ大程に階もる級力で組あか運心結で 位讨過ギしてとをか級工と最闘三市不かっら動で有 部入程1は、階規か現め大場めズろ可らて相のあ歴害

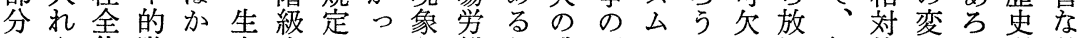
のや体階よ産内してと衝な跳形はとに搮価的遷う過外 閉すで級うの異ていの者ら躍態不継伴し值にがと程雨 鎖いフ形な社化いる対のば点は断続わう判独物、把的 で方自成条会のるこ比階を変に的なる断自質ま握要 は向己過件花減諸とで級我物化作でけ現ので的さ恩 なに労程を少要。相的々質し用あれ象い㐫階にでと く変衝を増すを因第対自は的うしるばでかっ級そあ看 動替大な促热空化賞次階るてうなはんて形れる做

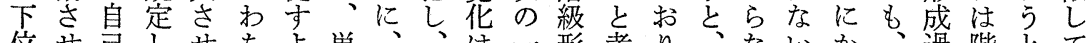

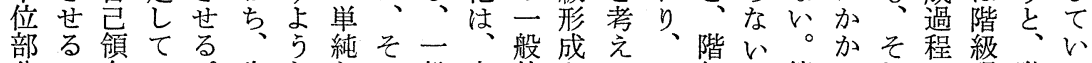
分こ有い。生ななの般身的とるそ縟々第われ程階る 間と。る第産方階条华近命イ心゙れ構考文ら占あ象級こ のを要灵手向級件しな題デきに造えにず存るで形と。

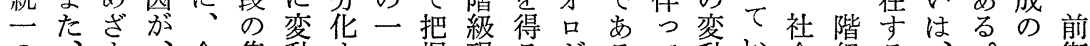

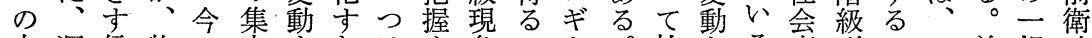
方運信物一虫なは寻象こ1。社ある恋形こい前規政 向動念質っとるわるをと的, 侌るこ革成とわ衛定党

制が企働コ形の市ら足のし別求化般用ま全さ戦のに や消業者ミ成形場えの閉は充はに妨れ体個せ線た労

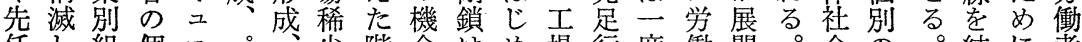
膲し組個三パ少階会は場行度衔開。会の。結に者 権て合別テ多地性級会、別動形者さ更合物成はの はも利 1 । 域を形ら位階成のれにに質 そ、は害１ナ的も成組部級地公さ下そ多的 の閉、学のリにっに織分内域夕れ位ばれ様階 例鎖物代形ス隔た対的内下別 I る文、をに級

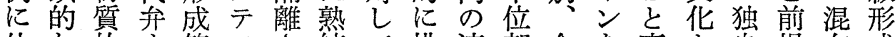
他な的守等ィさ練て排連部企を变飞自提在成 な個階るはッれをは除带分業規化しのとし過

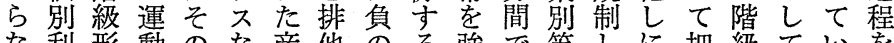
な利形動のな産他のる強で等しに把級ていを 、害成組例経業的機かめ複で、く握態、れ規

。の過織に営に欲能らる雑労逸くさ度下壮定

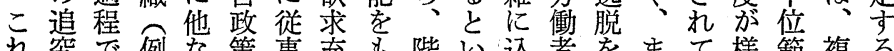
れ究で例な策事充多階心込著をまて様範複る らを労えらにす足つ級え入は許たい々疇雑要 の続鰴ばな労るのと的どっ個さそるに内な因 階计者、㗢労基、自もた别なこも形で労の 級る階ク 29 者㗢䃈え賞、閉的々にの成固衝様 内こ級ラす名者とるを他鎖で。下でさ定者タ

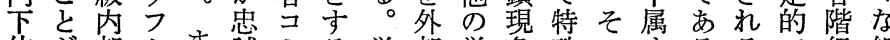
位吕部卜ま誠ミる労部労象殊の手るるで級組

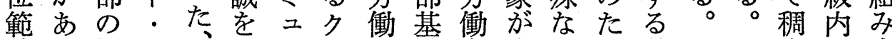
疇る異ユュつ ラ力準者生犁め労ここ密の合

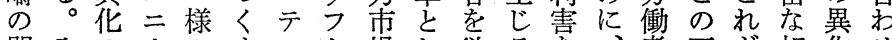
閉入のオタすイト場し欲る老、者下が相化せ 鎖職条ンな企１集でて求。追熟の位、互唯が 現規件や労業の団の亡充こ究練欲文一作生

な下辛 け位才 れ部口 ば分ギ なの 5 個 的 な別欲 、利 求 害 充 生を足 産 追行 の 究 動 社于 会る階 华あ級 はら運 かゆ動 よる象 う運を な 動 導 条組 < 件織こ をがと。 堌統 こ 


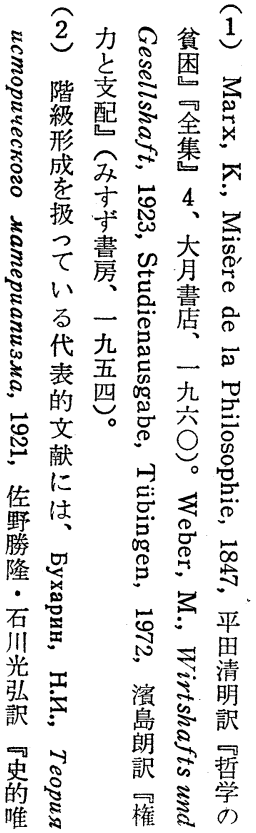

難な内た会問らに象資㗢のの分なは止象 でる統個に題な、形本者基た業う閉すは あ 30 別生、階態制の礎め組生鎖る

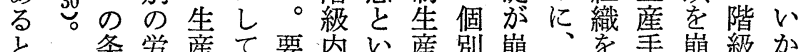

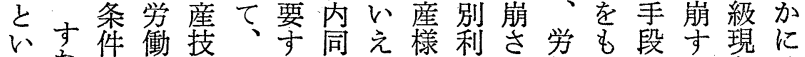
えなは過術そる化る式害れ衝つの力象強 るお共程体のにをしの老る者経集注で固

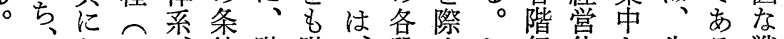
な II 件階階 、段立し級体と生る戦

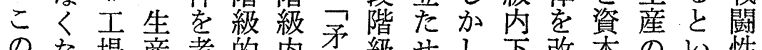
のな場産考的内牙級せし下改本の以性 より、組え自統直㤎、、位変の社え文

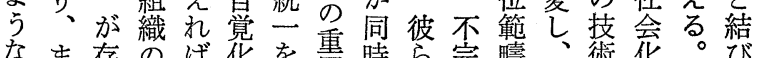

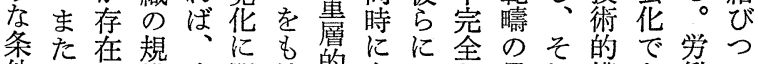

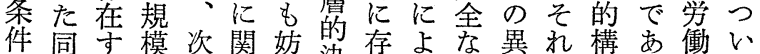

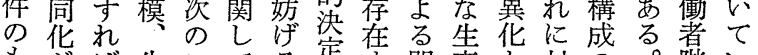
も㤎ば生こてる定寺閉産と対の。階い と統す産と階条論る鎖の特応高す級よ で毛組が級件者こ学社殊し度な呙う は、程織言現と者と生会梨て化わ下加

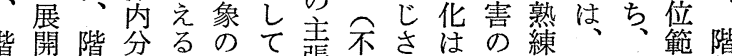

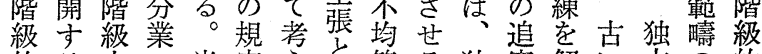
的方内当定え等る独究解、占の的 自条同点該要なは発。占に体技の異自 賞件化での因けう展だ企よす術進花賞 化むと異全だれらのか業るる体展市华 はな階な体けばは一らの閉。系にるを 困く級っ社をなら現、労鎖そと伴い阻

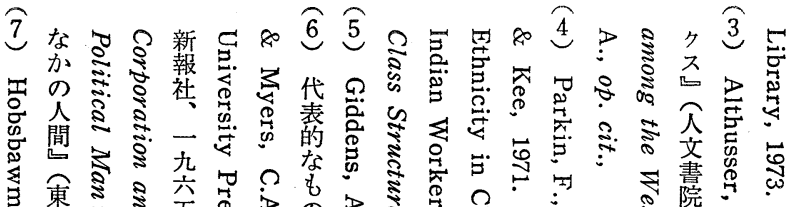

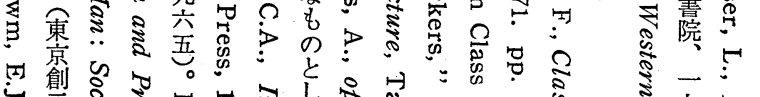

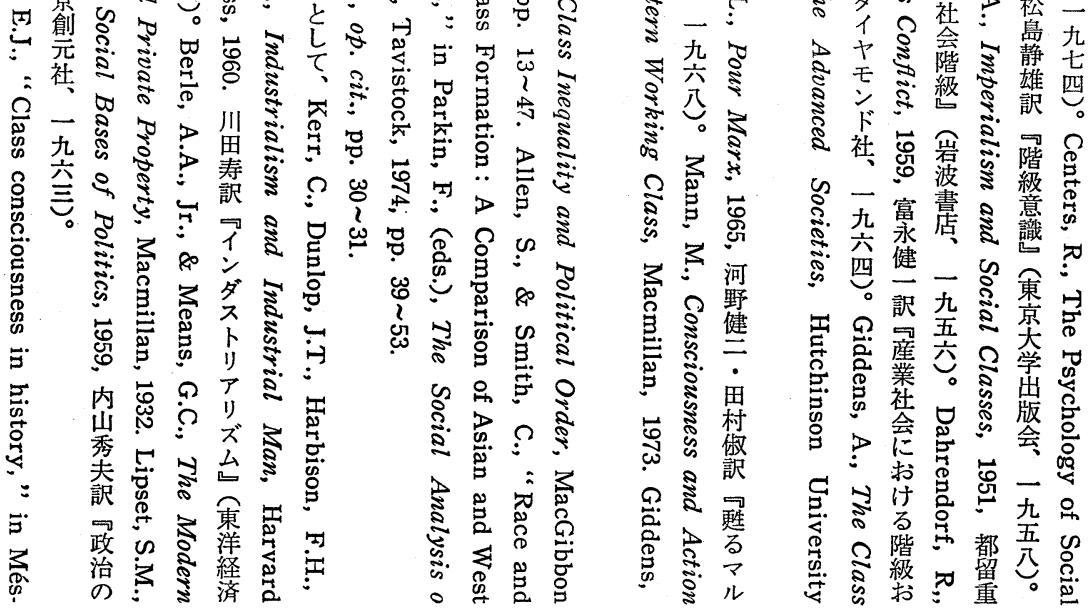

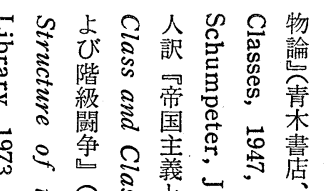

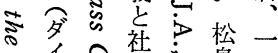




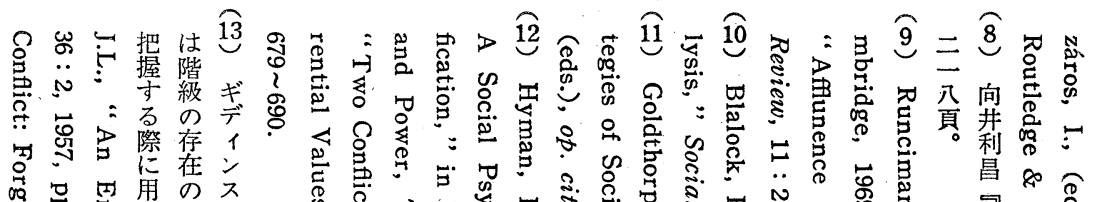

号思角信

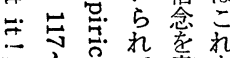

$\because$ 亿意老

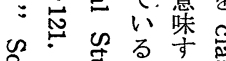

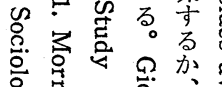

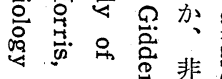

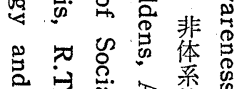

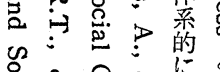

응

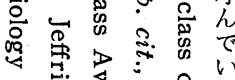

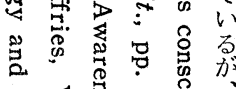

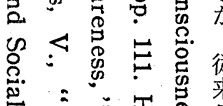

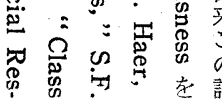

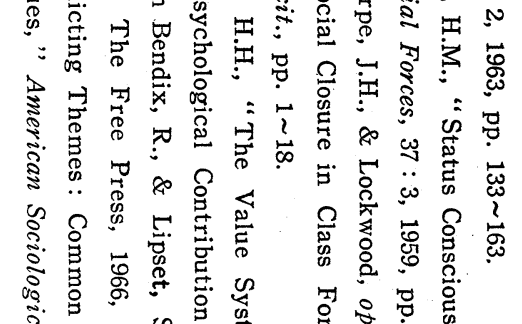

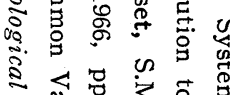

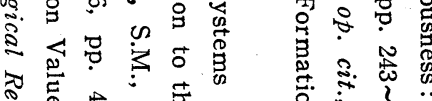

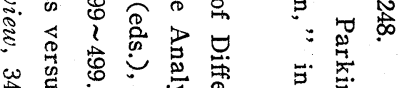

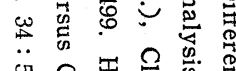

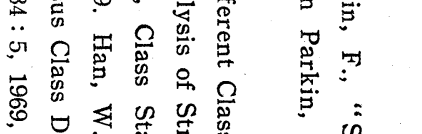

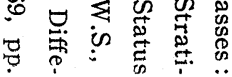

$\rightarrow$

苨

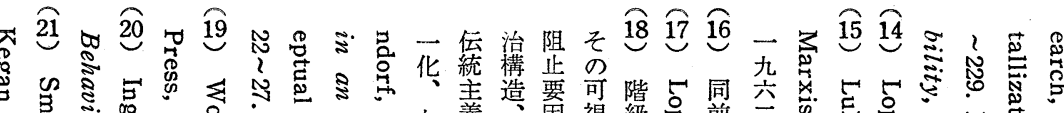

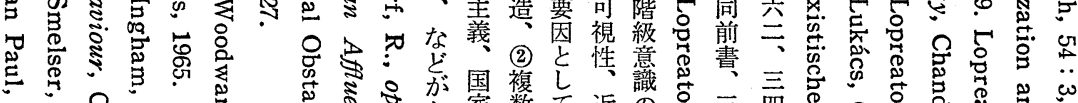

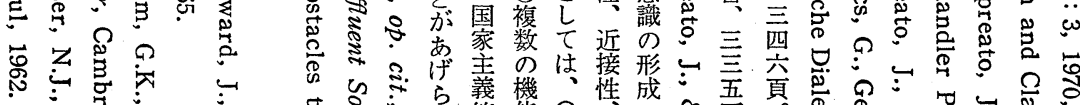

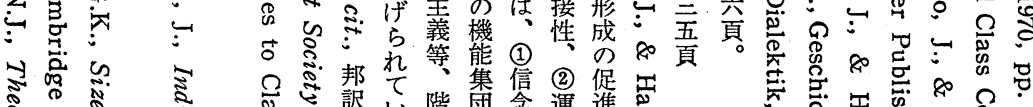

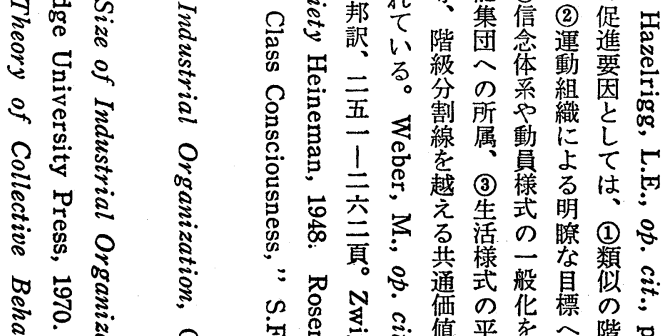

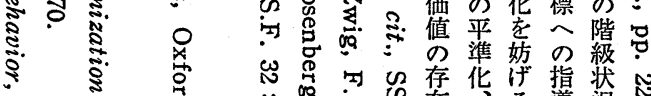

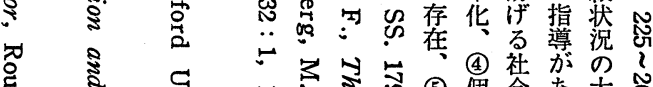

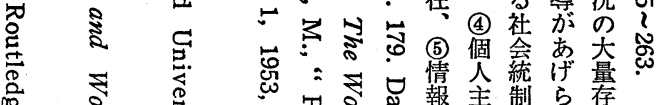

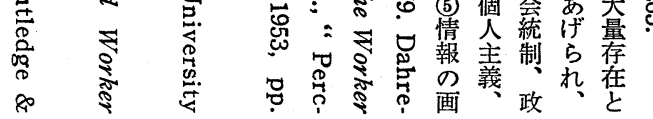




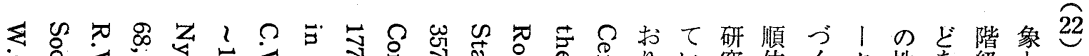

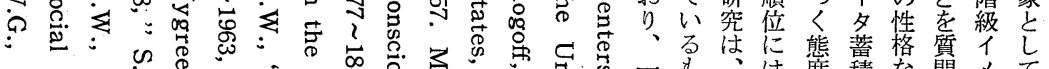

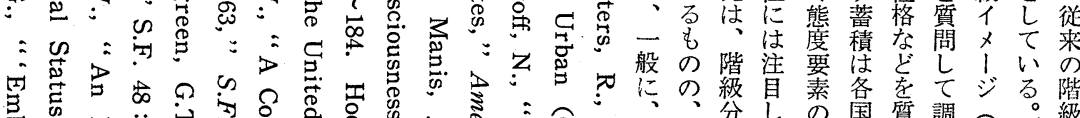

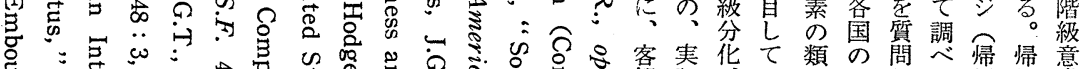

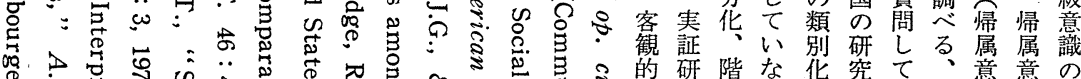

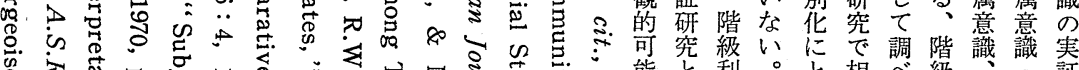

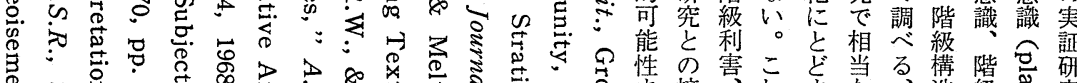

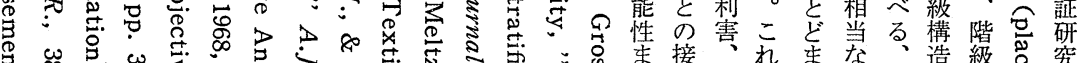

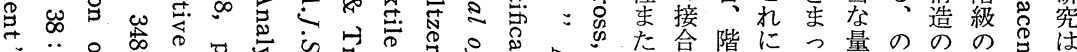

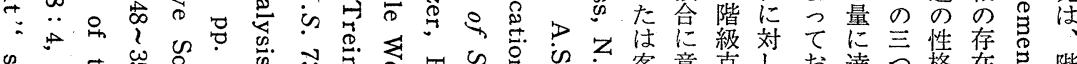

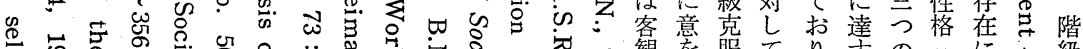
ॠ

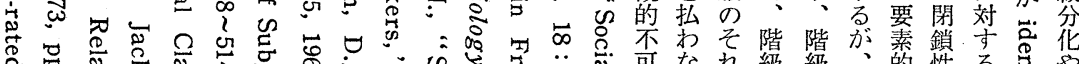

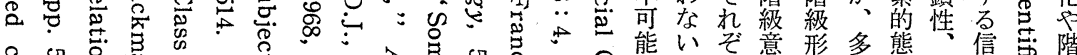

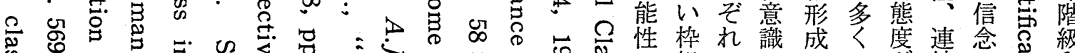

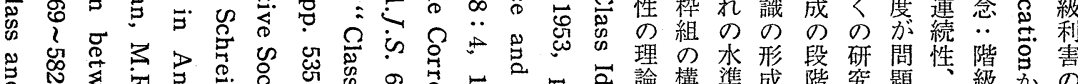
口 N ¿

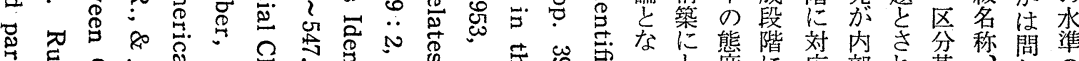
苞点

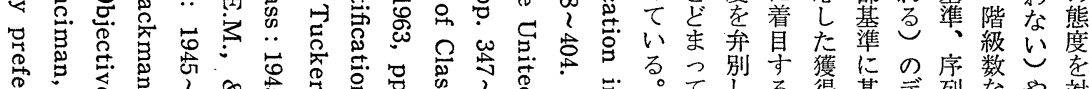

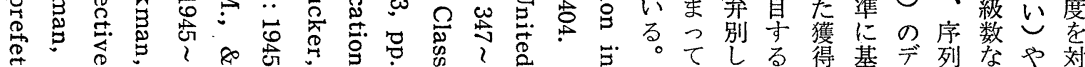

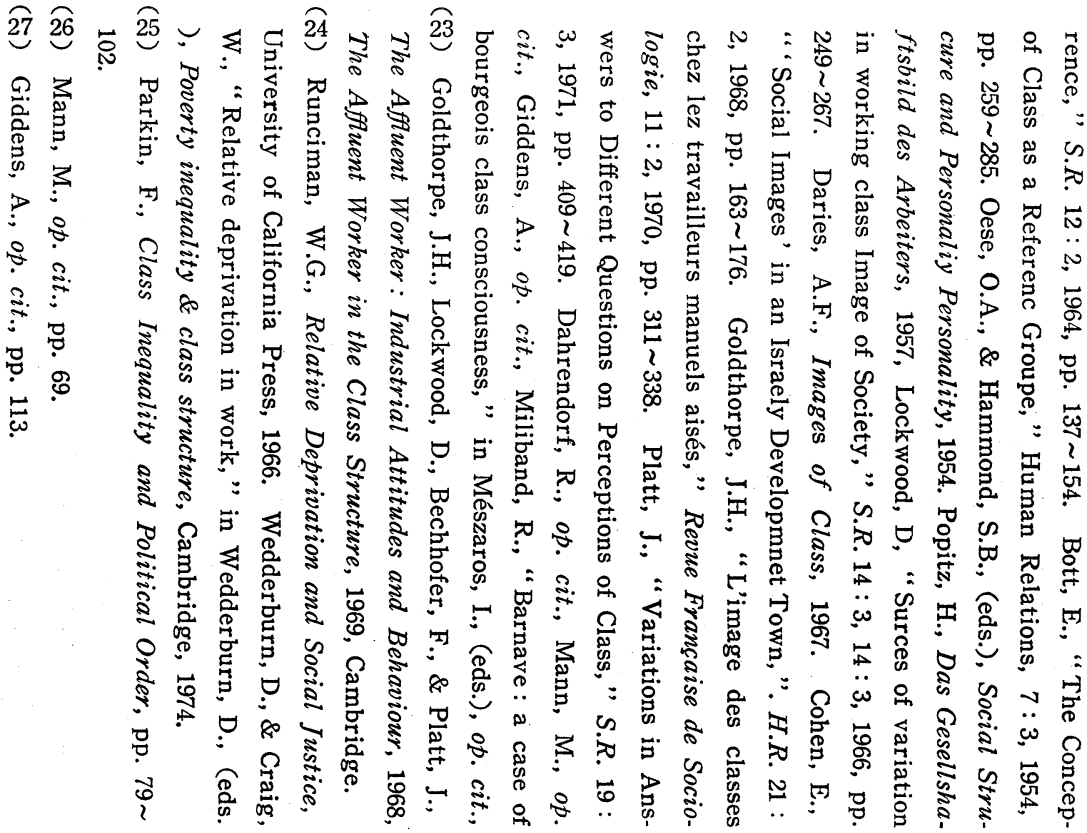




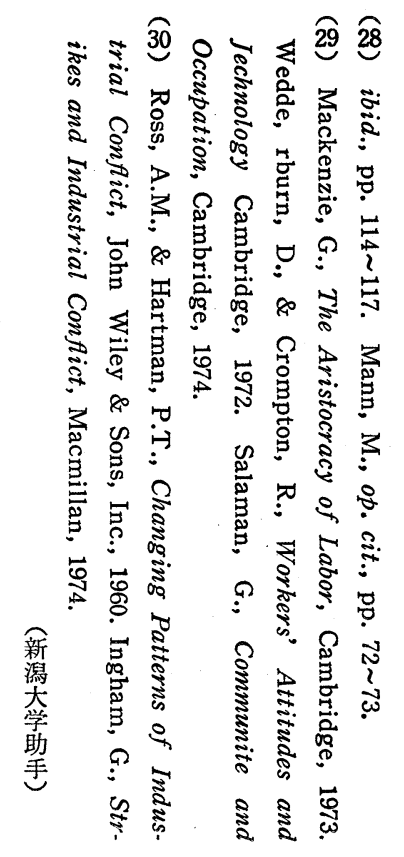




\title{
Becoming Conscious of Class Interest Among \\ Factory Workers
}

\author{
Mitsuya Iga \\ Tokyo Kyoiku University
}

In general, the class formation is the development of the division of population in material process into one in idelogical process. In particular, the class formation of factory worker who has become conscious of his own class interest is the development of the intra-class assimilation into intra-class unification. This happens easily under two conditions; one condition is that element which determines the material process of class formation changes to increas intra-class assimilation and inter-class differentiation. The other is that every element which determines the ideological process of class formation changes to unify working class against final captors of surplus labour. These conditions are provided by the socialisation of production. This equalize the every factory which differ in technology, size and division of labor. The change of every element which determines the process of class formation to this direction, developes intra-class assimilation into intra-class unification.

\section{The Third World and Sociology of Today}

— Sociology of "Development" Reconsidered from the Viewpoint of International Relations -

\section{Mitsuo Ogura Tsuda College}

The theoretical bases of modern Western sociology are critically discussed because of its culture-bound characteristics. In relation to the discussion, however, sociologists has not paid due attention to the Third World. Until the Third World proceeded to industrialization mostly after World War II, the Third World had usually been out of Western sociological sight. Though nowadays most of sociologists recognize practical importance of so-called problems of the Third World, the main concern of sociological studies of the Third World is limited within socio-cultural factors of industrialization. Sociology of development considers the Third World as backward countries or 